\title{
Shewanella putrefaciens Group
}

National Cancer Institute

\section{Source}

National Cancer Institute. Shewanella putrefaciens Group. NCI Thesaurus. Code C124398.

A non-hierarchical grouping of similar bacteria assigned to the Shewamella putrefaciens species. 